\title{
THE INFLUENCE OF ENVIRONMENTAL FACTORS ON FLOWERING OF FRENCH BEAN (PHASEOLUS VULGARIS L.)
}

\author{
Helena Labuda, Anna Brodaczewska \\ Department of Vegetable Crops and Medicinal Plants, University of Agriculture in Lublin, \\ Poland 20-068 Lublin, Leszczyńskiego 58 \\ e-mail: helena.labuda@ar.lublin.pl
}

Received: 25.09 .2007

$\mathrm{S} \mathrm{u} \mathrm{m} \mathrm{m} \mathrm{a} \mathrm{r} \mathrm{y}$

Observations of major development stages and flowering of four French bean (Phaseolus vulgaris L.) cultivars cultivated for green pods from six sowing dates (since mid of May till end of June) at weekly intervals were performed in 2003-2005. The study included the determination of the number of inflorescences per plant, number of flowers in inflorescence, length of inflorescence axis, and number of total and marketable pods per plant. French bean sown in the mid of May till the end of June showed the greatest variability with respect to the flowering start date and flowering period length as well as the number of pods set on a plant. French bean plants sown on different dates produced a similar number of inflorescences and flowers per bunch; 61.6-74.6 flowers per plant, on average. Weather conditions in July and August had the greatest influence on the flowering pattern and bean pod setting.

Key words: Phaseolus vulgaris L., French bean, flowering, date of sowing, green and yellow pod cultivars

\section{INTRODUCTION}

Bean (Phaseolus vulgaris L.) is cultivated in Poland for dry seeds and immature pods, i.e. as green bean - French bean (snap bean), which in general affects the crop technology of used cultivars.

French bean, due to a short vegetation period, may be cultivated with the sowing beginning from mid May till the end of June, which allows the pod harvest period to be extended to six-seven weeks when selecting only several cultivars. Environmental conditions, mainly air temperature and rainfall, greatly affect the growth and development of bean plants as well as they shape the plant's morphological traits and productivity (S zyrmer et al. 1992; Gros s and Ki ge 1, 1994; Mouhouche et al. 1998; Ibarra-Perez et al. 1999).
Research conducted by $\mathrm{Labuda}$ et al. (2006) reveals that snap bean sown in spring in a polyethylene unheated plastic tunnel showed worse pod setting on a plant and a shorter flowering period at air temperatures above $30-35^{\circ} \mathrm{C}$ at the stage of generative development.

When cultivated on a field under moderate climate conditions, common bean is more frequently exposed to low air temperatures, which influences flower and pod fading and dropping (G e o r g e , 1999).

In studies on factors determining the bean flowering, Wa 11 a c e et al. (1991) found that there was quite high interdependence between day length, temperature and cultivar traits. The optimum temperature for bean flowering at daily light of $12 \mathrm{hrs}$ was $27^{\circ} \mathrm{C}$, whereas the extension of daylight hours to $18 \mathrm{~h}$ allowed the optimum temperature for the bean plant flowering to be decreased to $18^{\circ} \mathrm{C}$.

This paper aims to evaluate the influence of six dates of French bean sowing at about weekly intervals since mid May till the end of June, on the course of major development stages, flowering abundance, and pod setting.

\section{MATERIALS AND METHODS}

The studies were conducted in 2003-2005 at the Experimental Farm Felin, University of Agriculture in Lublin, Poland.

Experimental material consisted of four French bean cultivars: Paulista and Hit - green-pod as well as Korona and Galopka - yellow-pod. Six sowing dates were applied: mid of May, end of May, May/June, beginning of June, mid of June, and end of June.

The double-factor experiment was set by means of randomized blocks in 4 replications. Each plot was of $4.05 \mathrm{~m}^{2}$ in area ( $3 \mathrm{~m}$ long and $1.35 \mathrm{~m}$ wide). Plants were 
sown in three rows at $0.45 \mathrm{~m} \times 0.08 \mathrm{~m}$ spacing on every plot. Fertilization and nursery operations were made in accordance with common recommendations for bean plants.

Observations were made of the course and length of major development stages together with flowering and pod setting for four bean cultivars cultivated from mid-May till the beginning of September.

Using 10 randomly selected plants (2-3 replications), the following items were determined: number of inflorescences per plant, number of flowers per inflorescence, length of inflorescence axis, and number of pods set on a plant - total and marketable.

The characteristics of weather conditions are presented on the basis of data obtained from the meteorological center at the Department of Agrometeorology, University of Agriculture in Lublin, located at the Experimental Farm Felin.

Measurement results were statistically processed by means of variance analysis and using Tukey's confidence intervals at the significance level of $\alpha=0.05$.

\section{RESULTS}

French bean plants manifested significant variability with respect to the start date and the length of particular development stages depending on the sowing date, cultivar and study year (Tab. 1).

In general, thermal conditions in 2003-2005 were more favorable than average ones in that area (Tab. 2).

The flowering stage - for various sowing dates - was observed from the end of June till the beginning of August, i.e. 28-42 days after emergence. The start of flowering of bean plants sown in mid-May occurred 37 days after emergence (the longest period), and the flowering started the earliest (32 days after emergence) in the plants sown at the end of May and beginning of June (Tab. 3).

The pattern of climatic factors in 2004, when air temperature since May till the end of June was lower as compared to long-term mean values, resulted in the delayed start date of flowering (42-43 days after emergence) for plants sown on the first dates. In 2003, when higher temperatures were recorded in May (by $3.2^{\circ} \mathrm{C}$ ), June (by $0.9^{\circ} \mathrm{C}$ ) and July (by $1.9^{\circ} \mathrm{C}$ ), the earliest flowering start was observed for bean plants sown in May (25-29 June), i.e. 30-32 days after emergence.

The length of the flowering stage for bean plants changed first of all due to the sowing date; it was 16-30 days during the study. The flowering period was the shortest for the earliest sown plants (19 days) and the longest (25 days) for bean plants with the sowing date in mid-June. Differences in flowering period length reached 6 days: the longest period ( 25 days) occurred in the cooler year 2004, the shortest one (19 days) under the conditions of high temperatures and insufficient rainfall during plant flowering in 2003 (Tab. 3).
Potential yielding abilities of legumes, including bean, depend not only on flowering period length, but also flowering abundance and the number of pods set on a plant.

The number of inflorescences per plant and flowers per inflorescence showed significant differences depending on the variety, sowing date and year of study. On average, the highest number of flowers was found for plants sown on the first three sowing dates (from midMay till the beginning of June). The number of flowers per inflorescence from the plants sown at the earliest date was significantly the lowest. Mean flower number per plant was the lowest in the plants sown late, in the middle and end of June (61.6-62.4) (Tab. 4, Fig. 1).

In the cooler year of 2004, bean plants produced a significantly lower number of inflorescences, but the number of flowers per inflorescence was higher. Bean inflorescences produced in 2004 were characterized by a significantly longer inflorescence axis $(20.1 \mathrm{~cm})$ as compared to those grown under higher temperature conditions in 2003 - they were three times shorter, on average.

The different sowing date for snap bean exerted a significant influence on the number of total and marketable pods set (Fig. 1). The significantly lowest number of total pods was found on the plants from the earliest and latest sowing dates, i.e. sown in the middle of May and the end of June (19.8 and 20.8, respectively). The number of marketable pods per plant was significantly the lowest from the earliest sowing date (12.4 pods, on average).

A comparison of six sowing dates of snap bean - from the middle of May till the end of June - reveals that flowering abundance was at similar levels, but pod setting was characterized by significant variability.

\section{DISCUSSION}

Common bean, as a thermophilic plant, requires $18-25^{\circ} \mathrm{C}$ for its proper growth and development. In field cultivation, the sowing should be made at about midMay, when the risk of spring frost is zero. However, as reports reveal ( $\mathrm{Sum}$ merfield and Roberts, 1984; Monterroso and Wien, 1990; Suzuki et al. 2001), bean plants are characterized by susceptibility to high temperatures during their generative growth. The negative influence of prolonged high temperature $\left(27-35^{\circ} \mathrm{C}\right)$ during flowering on pod setting was proven as well.

In the moderate climate, field plantations of bean are not exposed to long-lasting high temperatures. However, this phenomenon may occur in cultivations under polyethylene cover, which was confirmed by earlier studies by $€$ a b ud a et al. (2006). The research reveals that the flowering period for bean plants cultivated in the high plastic tunnel, where mean daily air temperature 
Table 1

Period of flowering of French bean cultivars from different sowing dates.

\begin{tabular}{|c|c|c|c|c|c|c|c|c|c|}
\hline \multirow{4}{*}{ Sowing date } & \multirow{4}{*}{ Years } & \multicolumn{8}{|c|}{ Observations } \\
\hline & & \multicolumn{4}{|c|}{ Start of flowering (date) } & \multicolumn{4}{|c|}{ End of flowering (date) } \\
\hline & & \multicolumn{8}{|c|}{ Cultivar } \\
\hline & & Paulista & Hit & Korona & Galopka & Paulista & Hit & Korona & Galopka \\
\hline \multirow{3}{*}{ May (middle) } & 2003 & 28.06 & 28.06 & 25.06 & 29.06 & 17.07 & 16.07 & 14.07 & 17.07 \\
\hline & 2004 & 13.07 & 12.07 & 07.07 & 11.07 & 29.07 & 29.07 & 27.07 & 28.07 \\
\hline & 2005 & 07.07 & 06.07 & 01.07 & 06.07 & 27.07 & 26.07 & 20.07 & 25.07 \\
\hline \multirow{3}{*}{ May (3 decade) } & 2003 & 02.07 . & 02.07 & 30.06 & 03.07 & 25.07 & 24.07 & 18.07 & 25.07 \\
\hline & 2004 & 16.07 & 16.07 & 14.07 & 15.07 & 09.08 & 09.08 & 04.08 & 06.08 \\
\hline & 2005 & 10.07 & 09.07 & 04.07 & 09.07 & 28.07 & 27.07 & 24.07 & 27.07 \\
\hline \multirow{3}{*}{ May / June } & 2003 & 06.07 & 06.07 & 05.07 & 07.07 & 26.07 & 27.07 & 25.07 & 27.07 \\
\hline & 2004 & 21.07 & 20.07 & 18.07 & 20.07 & 15.08 & 15.08 & 14.08 & 14.08 \\
\hline & 2005 & 10.07 & 09.07 & 05.07 & 09.07 & 03.08 & 02.08 & 29.07 & 02.08 \\
\hline \multirow{3}{*}{ May (1 decade) } & 2003 & 17.07 & 18.07 & 14.07 & 20.07 & 10.08 & 09.08 & 01.08 & 09.08 \\
\hline & 2004 & 24.07 & 24.07 & 21.07 & 23.07 & 23.08 & 23.08 & 17.08 & 18.08 \\
\hline & 2005 & 18.07 & 16.07 & 12.07 & 15.07 & 06.08 & 06.08 & 01.08 & 04.08 \\
\hline \multirow{3}{*}{ June (middle) } & 2003 & 23.07 & 24.07 & 22.07 & 25.07 & 12.08 & 13.08 & 06.08 & 13.08 \\
\hline & 2004 & 30.07 & 30.07 & 28.07 & 30.07 & 26.08 & 25.08 & 23.08 & 24.08 \\
\hline & 2005 & 20.07 & 18.07 & 13.07 & 18.07 & 17.08 & 18.08 & 12.08 & 16.08 \\
\hline \multirow{3}{*}{ June (3 decade) } & 2003 & 07.08 & 07.08 & 05.08 & 07.08 & 24.08 & 23.08 & 18.08 & 23.08 \\
\hline & 2004 & 02.08 & 02.08 & 29.07 & 30.07 & 29.08 & 27.08 & 23.08 & 24.08 \\
\hline & 2005 & 02.08 & 01.08 & 26.07 & 31.07 & 30.08 & 29.08 & 24.08 & 29.08 \\
\hline
\end{tabular}

Table 2

Mean decade air temperature $\left({ }^{\circ} \mathrm{C}\right)$ and total rainfall (mm) in 2003-2005 (experimental field, Felin-Lublin).

\begin{tabular}{|l|l|cccc|cccc|}
\hline \multirow{3}{*}{ Month } & \multirow{3}{*}{ Decade } & \multicolumn{3}{|c|}{ Mean decade air temperature $\left({ }^{\circ} \mathrm{C}\right)$} & \multicolumn{4}{c|}{ Mean decade total rainfall (mm) } \\
\cline { 3 - 9 } & & 2003 & 2004 & 2005 & $\begin{array}{c}\text { long-term mean } \\
1951-2000\end{array}$ & 2003 & 2004 & 2005 & $\begin{array}{c}\text { long-term mean } \\
1951-2000\end{array}$ \\
\hline \multirow{3}{*}{ May } & I & 16.5 & 13.6 & 10.8 & 11.6 & 8.9 & 10.1 & 32.8 & 16.6 \\
& II & 14.3 & 10.8 & 10.5 & 13.6 & 40.6 & 11.3 & 65.0 & 18.3 \\
& III & 17.8 & 11.4 & 18.0 & 13.7 & 21.9 & 16.6 & 0.2 & 23.5 \\
\hline \multirow{4}{*}{ June } & I & 19.1 & 15.7 & 13.4 & 16.0 & 2.6 & 3.7 & 47.1 & 20.8 \\
& II & 17.0 & 15.8 & 17.2 & 16.3 & 15.3 & 25.9 & 7.4 & 21.2 \\
& III & 16.1 & 16.1 & 17.4 & 17.1 & 21.7 & 20.3 & 1.4 & 23.8 \\
\hline \multirow{3}{*}{ July } & I & 17.5 & 17.1 & 18.9 & 17.4 & 24.9 & 4.7 & 0.0 & 23.5 \\
& II & 19.4 & 17.3 & 19.9 & 18.2 & 43.7 & 27.5 & 22.4 & 25.7 \\
& III & 22.4 & 20.0 & 20.4 & 18.0 & 29.5 & 58.3 & 87.4 & 29.0 \\
\hline \multirow{3}{*}{ August } & I & 20.1 & 19.0 & 16.5 & 18.5 & 0.7 & 14.7 & 103.9 & 23.8 \\
& II & 19.2 & 19.2 & 16.4 & 17.4 & 6.7 & 9.1 & 3.2 & 27.0 \\
& III & 17.5 & 17.0 & 17.8 & 15.9 & 19.6 & 24.7 & 1.6 & 19.3 \\
\hline
\end{tabular}


Table 3

The development stages of French bean growth depending on the sowing date (mean for cultivars).

\begin{tabular}{|c|c|c|c|c|c|c|c|c|}
\hline \multirow[b]{2}{*}{ Number of days } & \multicolumn{7}{|c|}{ Sowing date } & \multirow[b]{2}{*}{ Mean } \\
\hline & Years & 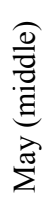 & 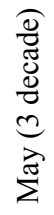 & $\begin{array}{l}\stackrel{\Xi}{\Xi} \\
\stackrel{\vec{\Xi}}{\Sigma}\end{array}$ & 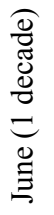 & 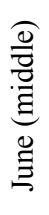 & 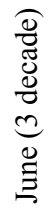 & \\
\hline \multirow{4}{*}{ Sowing - emergence } & 2003 & 13 & 12 & 7 & 7 & 7 & 6 & 8 \\
\hline & 2004 & 12 & 8 & 13 & 12 & 9 & 10 & 11 \\
\hline & 2005 & 7 & 5 & 10 & 9 & 6 & 7 & 7 \\
\hline & Mean & 11 & 8 & 10 & 9 & 7 & 8 & 9 \\
\hline \multirow{4}{*}{ Emergence - flowering } & 2003 & 32 & 30 & 32 & 36 & 35 & 39 & 34 \\
\hline & 2004 & 42 & 43 & 36 & 33 & 36 & 29 & 36 \\
\hline & 2005 & 38 & 39 & 28 & 30 & 29 & 33 & 33 \\
\hline & Mean & 37 & 37 & 32 & 33 & 33 & 34 & 34 \\
\hline \multirow{4}{*}{ Flowering period } & 2003 & 19 & 21 & 20 & 21 & 19 & 16 & 19 \\
\hline & 2004 & 18 & 23 & 26 & 28 & 26 & 26 & 25 \\
\hline & 2005 & 20 & 19 & 24 & 20 & 30 & 29 & 24 \\
\hline & Mean & 19 & 21 & 23 & 23 & 25 & 24 & 22 \\
\hline \multirow{4}{*}{ Start of podding - harvest } & 2003 & 22 & 22 & 20 & 22 & 22 & 16 & 20 \\
\hline & 2004 & 24 & 22 & 26 & 29 & 29 & 31 & 27 \\
\hline & 2005 & 25 & 25 & 26 & 25 & 32 & 34 & 28 \\
\hline & Mean & 24 & 23 & 24 & 25 & 28 & 27 & 25 \\
\hline
\end{tabular}

ranges from $20.4^{\circ} \mathrm{C}$ to $27.3^{\circ} \mathrm{C}$, was $25-32$ days, while at $11.4-22.4^{\circ} \mathrm{C}$ and on the field - up to $31-37$ days. The number of pods set on a plant was 13-22, and 24.5-35.5 in the plastic tunnel and on the field, respectively.

Gros s and Kigel (1994) found that the poorest pod setting was observed for common bean exposed to high temperatures 1-6 days before flowering. The study of I b a r r a -P e r e z et al. (1999) reveals that poorer pod setting on common bean (as a self-pollinating plant) may occur in the absence of pollinating insects, which was proven for some dwarf cultivars.

Flower and pod falling is a common phenomenon, which may result from insufficient flower pollination, depending on genetic background, or be an effect of different availability of plant-origin assimilates and hormones. At higher soil humidity and with shortened daylight hours, plants produce many flowers, but only $7-12 \%$ of them set pods. With a lower soil moisture content and longer daylight hours, plants form a lower number of flowers, but $17-24 \%$ of them produce pods, and therefore the yield is higher ( $\mathrm{Prusinski}$ and B or ow s k a, 2002).

It follows from the present study that the number of total pods on French bean plants sown at various dates from 19.8 (mid-May sowing) to 26.7 (end of May and beginning of June sowing). The flowering period of French bean varied, mainly depending on the sowing dates and study years, amounting from 16 to 29 days. Differences in flowering period lengths for plants sown on different dates were 2-6 days, while with respect to the studied cultivars 1-2 days.

W i l c z e k and Ć w in t a l (2003) indicated that very high air temperatures, great insolation, and low rainfall much shortened the period of red clover flowering, whereas low temperatures along with high and frequent precipitation resulted in the prolongation of the plant's 


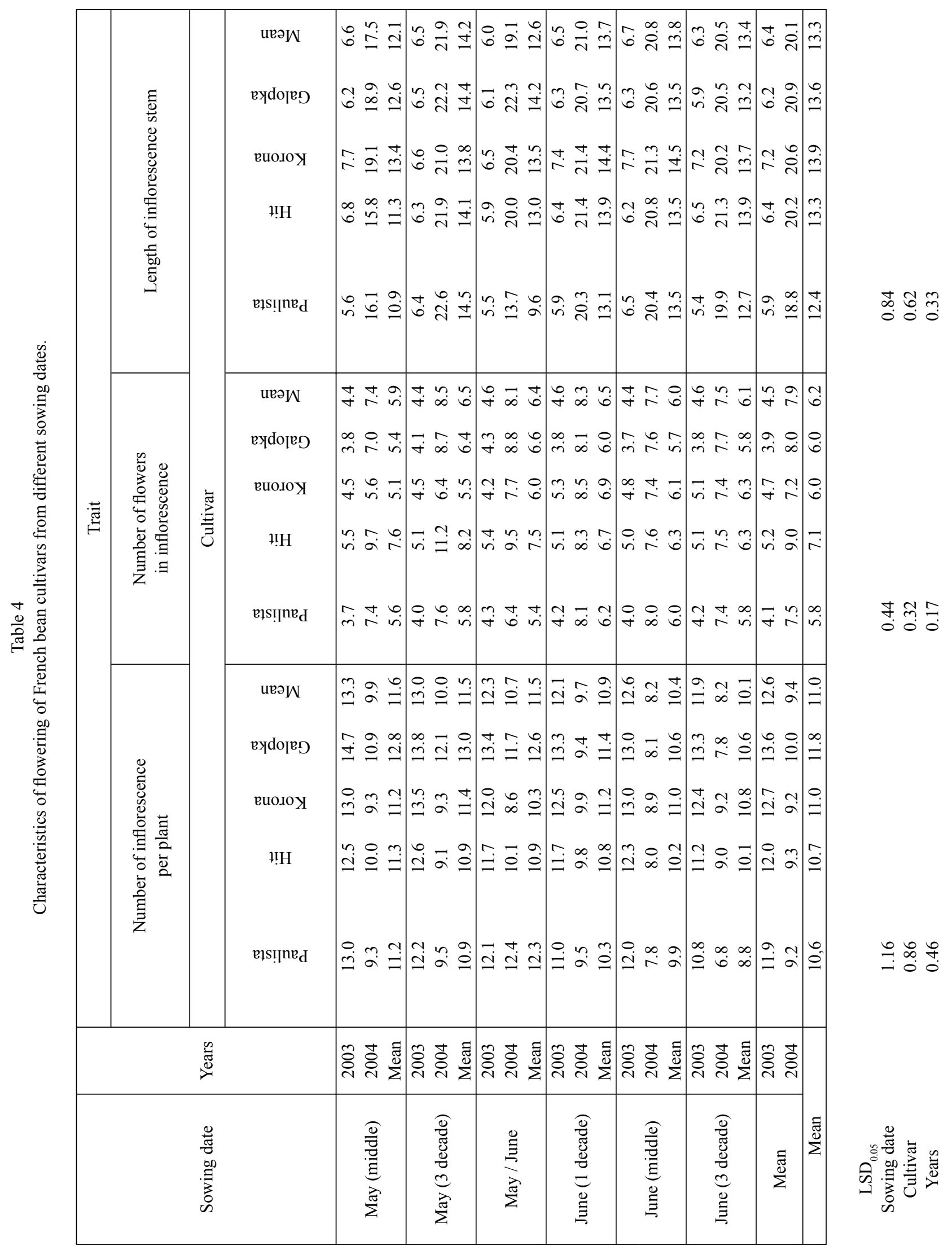




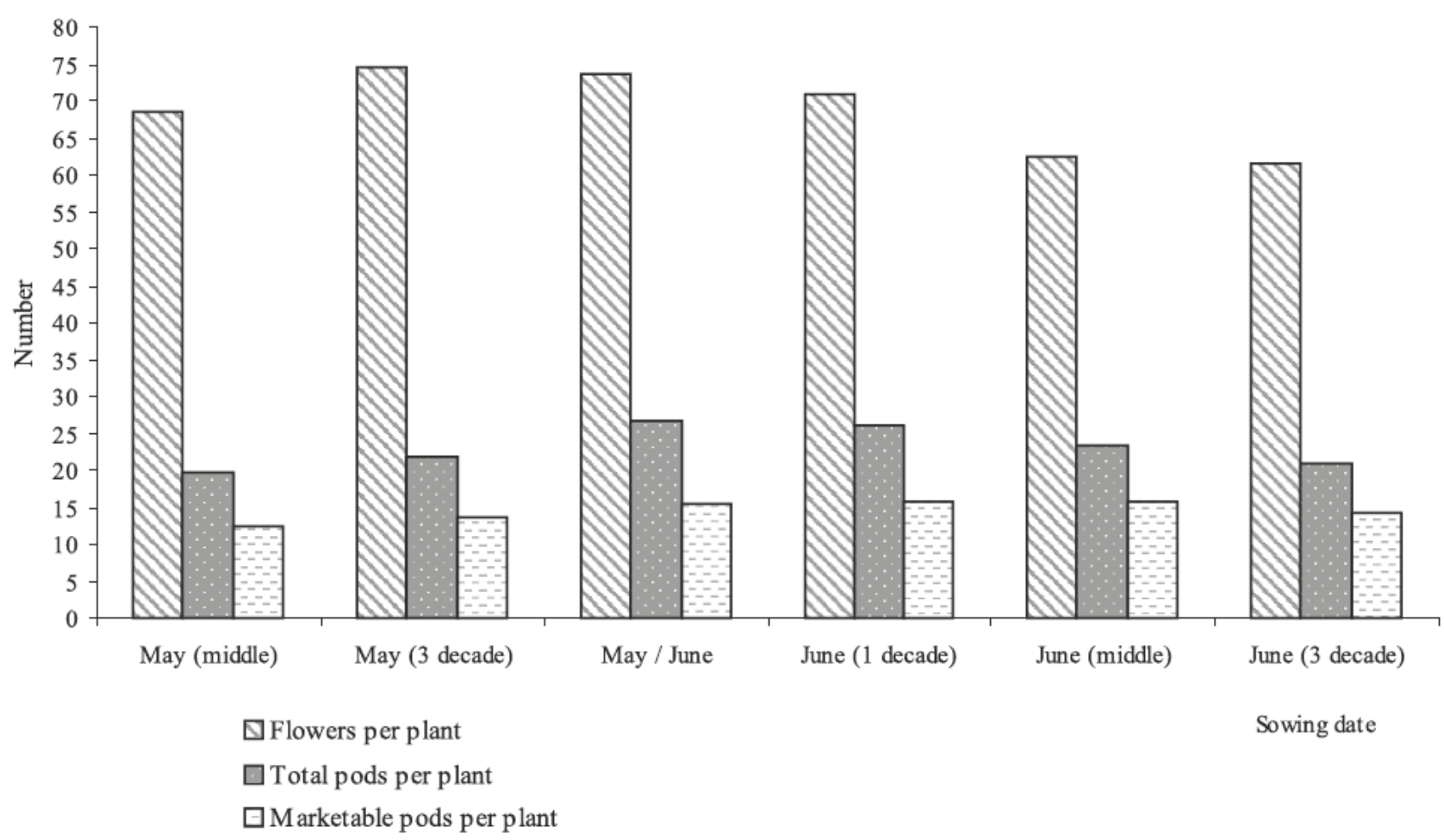

Fig. 1. Flowering and pod setting of French bean from different sowing dates (mean for cultivars and study years).

flowering even to 40-50 days and made the work of pollinating insects difficult.

Wallace et al. (1991) proved a significant shortening of the period to the beginning of plant flowering along with the increase of air temperature in the range of $12-28^{\circ} \mathrm{C}$.

In the cultivation of bean sown on different dates, the number of inflorescences per plant varied and it was the largest from the plants sown in mid-May, and flowers per inflorescence from the plants sown in the end of May and the beginning of June. The mean number of flowers per plant varied from 61.6 to 74.6 , and it was similar to the values cited in other studies of Wr o blewska (1991) for common bean.

K o c on et al. (1997) in a study on the influence of nitrogen fertilization on flowering and fruiting of faba bean found that abundant flowering did not reflect in the number of pods set or seed yield. Forming a low number of pods or their early fading and falling may be an effect of nitrogen or other minerals deficiency at the generative stage of plant development. The number of inflorescence shoots, levels in inflorescence, and flowers per bunch determine the biological potential of a legume.

The results obtained in the present study are confirmed by other authors' reports on great variability of yield-forming traits, including the number of pods set per plant, depending on environmental factors and features of cultivars (B e a ver et al. 1994; Mouhouche et al. 1998; Nielsen and Nels on, 1998; Ferreira et al. 2000).
Experiments performed in Croatia (B o r o s i c et al. 2000) revealed that the prolongation of the period harvesting till the middle of October was achieved in the cultivation of French bean sown at the end of June and in mid-July. The number of pods per plant significantly varied within the range of 4.3-11.5, depending on the study year. Those authors discovered, as in the present study, that the emergence of bean sown in the middle of June was uniform and fast: it occurred after 6-7 days (Borosic et al. 2000).

Results of studies conducted under other climatic conditions (Bangladesh) also confirmed a significant influence of the date of bean sowing on its morphological and reproduction traits as well as the yield size $(\mathrm{B} \mathrm{e}$ $\mathrm{g} \mathrm{u} \mathrm{m}$ et al. 2003). This author's own study revealed that higher bean pod and seed yields were achieved from January as compared to February sowing.

\section{CONCLUSIONS}

1. The development and yield-forming traits of French bean (Phaseolus vulgaris L.) varied depending on the sowing date, the plant's genetic features and greatly on atmospheric conditions during the vegetation period.

2 . French bean sown from the middle of May till the end of June showed the greatest variability with respect to the start and length of flowering periods as well as the number of pods set on a plant.

3. French bean plants sown on different dates produced from 61.6 to 74.6 flowers: the least from the 
late sowing date (end of June). Weather conditions in July and August had the most significant influence on flowering and pod setting in French bean.

\section{REFERENCES}

Beaver J. S. Roman-Hernandez O., 1994. Green shell bean production in Puerto Rico at different planting dates. J. Agric. Univ. Puerto Rico. 78: 331-336.

B egum A., Ahad A., Kais ar M. O., Islam M. M., Anam M. K., 2003. Effect of sowing dates and fertilizer treatments on the reproductive variability of French bean (Phaseolus vulgaris). Pakistan J. Biological Sci. 6(22): 1897-1901.

Borosic J., Romic D., Dolanjski D., 2000. Growth and yield components of dwarf french bean grown under irrigation conditions. Acta Hortic. 533: 451-459.

Ferreira M. E., Ferreira A., Monteiro A. A., de Melo e A breu J. P., Bi an co V. V., 2000. A simple weather driven model to determine harvest date of green beans for freezing using quantitative and qualitative criteria. Acta Hortic. 533: 489-495.

George R. A. T., 1999. Vegetable seed production $2^{\text {nd }}$ Edition. Leguminosae. French bean Phaseolus vulgaris L. Runner bean Phaseolus coccineus L. CABI Publishing Longman. London - New York: 196-204.

Gross Y., Kigel J., 1994. Differential sensitivity to hight temperature of stages in the reproductive development of common bean (Phaseolus vulgaris L.). Field Crops. Res. 36: 201-212.

Ibarra-Perez F. J., Barnhart D., Ehdaie B., Knio K. M., Waines J. G., 1999. Effects of Insect Tripping on Seed Yield of Common Bean. Crop. Sci. 39: 428-433.

Kocoń A., Wojcieska U., Podleśna A., Głażewski S., 1997. Wpływ żywienia azotem na kwitnienie i owocowanie bobiku. / Effect of nitrogen nutrition on the flowering and pool setting of faba bean Mater. I Ogólnopol. Konf. Nauk. „Biologia kwitnienia, nektarowania i zapylania roślin. Lublin 13-14 listopada. 136-141.

Łabuda H., Baran A., Papliński R., 2006. Kwitnienie i zawiązywanie strąków siedmiu odmian fasoli szparagowej (Phaseolus vulgaris L.) w zróżnicowanych warunkach uprawy. / Flowering and pod setting of seven snap bean cultivars (Phaseolus vulgaris L.) under various crop conditions. Acta Agrobot. 59(1): 439-446.

Monterroso V. A., Wien H. Ch., 1990. Flower and pod abscission due to heat stress in beans. J. Amer. Soc. Hortic. Sci. 115(4): 631-634.

Mouhouche B., Ruget F., Delécolle R., 1998. Effects of water stress applied at different phenological phases on yield components of dwarf bean (Phaseolus vulgaris L.). Agronomie, 18: 197-205.

Nielsen D. C., Nelson N. O., 1998. Black Bean Sensitivity to Water Stress at Various Growth Stages. Crop Sci. 38: 422-427.
Prusiński J., Borowska M., 2002. Potencjał biologiczny roślin strączkowych i jego wykorzystanie. Cz. I. Zastosowanie regulatorów wzrostu w uprawie roślin strączkowych. / Biological potential leguminous plant and their using. P.I. Used of growth regulators in leguminous plant cultivation. Hodowla Roślin i Nasiennictwo, 2: 33-38.

Summerfield R. J., Roberts E. H., 1984. Phaseolus vulgaris. [In:] Handbook of flowering A.H. Halevy (ed). Vol. I, CRC, Press Boca Raton. Fl.: 139-147.

Suzuki K., Takeda H., Tsukaguchi T., Egawa Y., 2001. Ultrastructural study on degeneration of tapetum in anther of snap bean (Phaseolus vulgaris L.) under heat stress. Sex Plant Reprod. 13: 293-299.

Szyrmer J., Dembińska J., Wawer A., 1992 Przebieg wegetacji i zmienność cech użytkowych odmian i form Phaseolus vulgaris $\mathrm{L}$. / The vegetation pattern and variability of useful traits of cultivars and forms of Phaseolus vulgaris L. Biul. Inst. Hod. Aklim. Rośl. 180: 229-239.

Wallace D. H., Gniffke P.A., Masaya P. N., Zobel R. W., 1991. Photoperiod, temperature, and genotype interaction effects on days and nodes required for flowering of bean. J. Amer. Soc. Hort. Sci. 116, 3: 534-543.

Wilczek M., Ćw intal M., 2003. Wpływ warunków pogodowych i glebowych na długość kwitnienia nasiennej koniczyny czerwonej. / The influence of weather and soil conditions on red clover flowering length. Ann. Univ. Mariae Curie-Skłodowska, Sect. EEE Hortic. 13: 263-269.

Wróblewska A., 1991. Attractiveness of Phaseolus L. flowers for pollinating insects. Acta Hortic. 288: 321-325.

\section{Wpływ warunków środowiskowych na przebieg kwitnienia fasoli szparagowej (Phaseolus vulgaris L.)}

\section{Streszczenie}

W latach 2003-2005 przeprowadzono obserwacje ważniejszych faz rozwojowych oraz przebieg kwitnienia czterech odmian fasoli szparagowej (Phaseolus vulgaris L.) uprawianej z sześciu terminów siewu (od połowy maja do końca czerwca) w odstępach tygodniowych. Określono: liczbę kwiatostanów na roślinie, liczbę kwiatów w kwiatostanie, długość osi kwiatostanowej oraz liczbę strąków ogółem i handlowych na roślinie. Fasola szparagowa z siewu od połowy maja do końca czerwca wykazywała największą zmienność pod względem terminów początku kwitnienia i długości fazy kwitnienia oraz liczby zawiązywanych na roślinie strąków. Rośliny fasoli szparagowej z różnych terminów uprawy wytwarzały zbliżoną liczbę kwiatostanów i kwiatów w gronie, średnio 61,6-74,6 kwiatów na roślinie. Największy wpływ na przebieg kwitnienia i zawiązywania strąków fasoli szparagowej miały warunki pogody w lipcu i sierpniu. 
